\title{
Bimbingan Karier Dalam Media Portofolio Karier
}

\author{
Nida'u Diana ${ }^{1}$, M. Ramli ${ }^{1}$, Muslihati ${ }^{1}$ \\ ${ }^{1}$ Bimbingan dan Konseling-Universitas Negeri Malang
}

\section{INFO ARTIKEL}

\section{Riwayat Artikel:}

Diterima: 03-01-2020

Disetujui: 13-07-2020

\section{Kata kunci:}

career guidance; career portfolio; high school student; bimbingan karier; portofolio karier; siswa SMA

\author{
Nida'u Diana \\ Bimbingan dan Konseling \\ Universitas Negeri Malang \\ Jalan Semarang 5 Malang \\ E-mail: annidadian@gmail.com
}

\section{ABSTRAK}

Abstract: Development of a career portfolio guide for students of senior high school Bayt Al-Hikmah is a guide to career guidance activities that explore students' selfunderstanding in documenting and administering student learning outcomes in the form of career portfolios. Purpose of this research is to produce guidelines for students' career portfolios that are acceptable, in terms of accuracy, usability, convenience, and attractiveness. The design of the development uses the modified Borg and Gall (1983) R\&D model. Data collection uses product assessment instruments by BK experts and media experts analyzed using inter-rater agreement techniques, with high index results in product acceptance in terms of accuracy, usability, convenience, and interest.

\begin{abstract}
Abstrak: Pengembangan panduan portofolio karier bagi siswa SMA Bayt Al-Hikmah adalah panduan kegiatan bimbingan karier yang menggali pemahaman diri siswa dalam mendokumentasikan dan mengadministrasikan hasil rekam jejak belajar siswa dalam bentuk portofolio karier. Tujuan penelitin ini adalah menghasilkan panduan portofolio karier siswa yang berterima, dari segi ketepatan, kegunaan, kemudahan, dan kemenarikan. Rancangan pengembangan menggunakan model R\&D Borg and Gall yang dimodifikasi. Pengumpulan data menggunakan instrumen penilaian produk oleh Ahli BK dan ahli media yang dianalisis menggunakan teknik inter-rater agreement, dengan hasil indeks tinggi dalam keberterimaan produk pada hal ketepatan, kegunaan, kemudahan, dan kemenarikan.
\end{abstract}

Bimbingan dan Konseling merupakan layanan sistematis, objektif, logis, berkelanjutan dan terprogram yang dilaksanakan oleh guru bimbingan dan konseling atau konselor untuk memfasilitasi perkembangan siswa dalam mencapai kemandirian (Kemendikbud, 2016). Guru bimbingan dan konseling, harus dapat mengevaluasi perkembangan siswa, sesuai kebutuhan perkembanganya yang dapat dirujuk dari SKKPD. Sebagai komponen yang terpadu dalam sistem pendidikan, bimbingan dan konseling memfasilitasi perkembangan siswa untuk mencapai kemandirian, dalam wujud kemampuan memahami diri dan lingkungan, menerima diri, mengarahkan diri, dan mengambil keputusan, serta merealisasikan diri secara bertanggung jawab, sehingga tercapai kebahagiaan dan kesejahteraan dalam kehidupannya. Bagi guru BK/konselor, penggunaan teknik-teknik konseling merupakan pertanggungjawaban ilmiah dan teknologi dalam menyelenggarakan konseling (Kemendikbud, 2017).

BK memiliki fungsi: preventif; pengembangan; dan pengentasan atau kuratif. Tiga fungsi tersebut terwujud dalam struktur program dan kegiatan BK. Di zaman milenial ini banyak terjadi perubahan paradigma pendekatan bimbingan dan konseling, dari yang berorientasi tradisional, remediatif, klinis, dan terpusat pada konselor, beralih ke pendekatan yang berorientasi perkembangan dan pencegahan. Bimbingan dan Konseling dikembangkan sesuai fitrah manusia sebagai makhluk yang berdimensi biologis, psikis, sosial, dan spiritual (ABKIN, 2007). Hakikat dan fungsi layanan Bimbingan dan Konseling diwujudkan dalam program yang dikembangkan sesuai kebutuhan siswa dalam empat komponen program pelayanan, yaitu: layanan dasar; layanan responsif; perencanaan individual dan dukungan sistem (Muslihati, 2019). Dalam penelitian pengembangan ini, peneliti mencoba mengembangkan media bagi guru BK/Konselor dalam layanan bimbingan karier melalui buku panduan yang memandu kegiatan siswa yang menhasilkan portofolio karier, sebagai bagian layanan preventive dan development.

Hasil evaluasi peneliti selama mendidik dua tahun terakhir, dan dilihat dari data tabel perkembangan diri siswa melalui kegiatan ekstrakurikuler laporan perkembangan siswa siswa SMA Bayt Al-Hikmah masih memiliki perencanaan karier yang cukup rendah, terutama dalam kesiapan administrasi hasil rekam jejak belajarnya yang tidak terdokumentasikan dengan rapi, baik itu yang bersifat hasil tugas harian, dan beberapa projek belajar yang melibatkan kepanitiaan besar masih kurang terdokumentasikan dengan rapi. Sebagian besar siswa kurang peduli terhadap surat-surat keputusan dalam sebuah kegiatan serta sertifikat yang mereka dapat dari setiap kegiatan yang dilakukan. Dari hasil evaluasi di atas, lemahnya perencanaan karier siswa disebabkan beberapa hal antara lain, lemahnya pemahaman diri, kurang mengeksplorasi karier, perbedaan keinginan orang dewasa dan anak sehingga berpengaruh pada keputusan karier siswa. 
Portofolio Karier merupakan salah satu cara yang dapat memfasilitasi siswa dalam menempatkan rencana kerja, dan rencana studi lanjutnya dalam bentuk portofolio (Juwitaningrum, 2013). Menurut beberapa penelitian yang menggunakan portofolio sebagai media perencanaan karier cukup efektif digunakan dalam bimbingan karier bagi siswa. (Oscario and Zahra, 2016), memang sebagian besar penggunaan media portofolio lebih sering digunakan oleh siswa pada bidang desain dan kejuruan, namun semakin berkembang bidang pendidikan maka media portofolio dapat digunakan oleh semua bidang penjurusan sebagai salah satu teknik dalam perencanaan dan kematangan karier siswa (Prastiwi, 2015). Dengan demikian, peneliti tertarik untuk mengguakan media panduan portofolio karier untuk membimbing siswa dalam kegiatan yang menghasilkan portofolio karier. Beberapa penelitian serupa juga dikembangkan ditingkat se rier siswa dalam buku panduan, yanghasilnya cukup efektif. Pengembangan lain dalam pendidikan dasar yakni, sekolah menengah atas di MAN Sidoarjo dalam penelitianya (Sari \& Nuryono, 2014) yakni Pengembangan Buku Panduan Orangtua dalam Perencanaan Karier Siswa, dimana dalam pengembangan tersebut mengangkat perencanaan ka pengembangan kartu karier untuk bimbingan karier siswa sekolah dasar yang hasilnya juga cukup efektif dalam menghasilkan portofolio karier (Hanani, 2016).

Fungsi pengembangan panduan Portofolio karier adalah untuk mengoptimalkan fungsi layanan peminatan dan perencanaan karier siswa di SMA Bayt Al-Hikmah. Peran guru BK atau konselor dalam pengembangan panduan ini adalah sebagai fasilitator dalam membimbing siswa pada kegiatan yang menghasilkan portofolio. Produk yang dihasilkan dari penelitian pengembangan ini adalah berupa buku panduan portofolio karier Bagi Siswa SMA Bayt Al-Hikmah, pengembangan ini ditujukan untuk guru BK atau konselor dan juga untuk siswa di SMA Bayt Al-Hikmah. Adapun fungsi pengembangan panduan ini adalah (1) mengoptimalkan peran guru BK atau konselor sebagai fasilitator dalam bimbingan dan layanan karier siswa melalui panduan kegiatan yang dapat menghasilkan portofolio dan (2) fungsi bagi siswa adalah mengoptimalkan kesadaran diri siswa dengan kegiatan yang dapat menghasilkan portofolio, kemudian mendokumentasikan, dan mengadministrasikan hasil rekam jejak belajarnya dalam map portofolio sehingga kelak lebih siap dalam dokumen persyaratan yang dibutuhkan sesuai perencanaan dan pilihan karier siswa kedepanya.

Frank Parsons (Atmaja, 2014) menyatakan bahwa dalam memilih karier seorang individu idealnya harus: mengenali diri sendiri, sikap, minat ambisi, batasan sumber dan akibatnya. Kedua, Pengetahuan tentang kesuksesan dan kerugian, kompensasi, kesempatan, dan harapan masa depan pada jenis pekerjaan. Ketiga, Pengetahuan mengenai hubungan kondisi realita dan fakta sebelumnya. Dalam perspektif Traits and Factor ada faktor dari dalam diri individu yang dapat digunakan untuk mengenali diri sebagai usaha perencanaan karir yang matang. Langkah-langkah yang digunakan adalah menganalisis diri, memanfaatkan informasi jabatan, dan mengimplementasikan cara berfkir rasional untuk menemukan kecocokan antara ciri-ciri pribadi yang mempunyai relevensi terhadap kesuksesan atau kegagalan dalam suatu pekerjan atau jabatan, dengan tuntutan kualifikasi dan kesempatan yang terkandung dalam suatu pekerjaan/jabatan. Sesuai dengan standart kompetensi kemandirian peserta didik (SKKPD) bahwa pada siswa tinngkat SLTA memiliki sebelas aspek tugas perkembangan yang dijadikan acuan. Salah satu aspek perkembangan tersebut yang mengarah pada bidang karir ialah aspek perkembangan wawasan dan kesiapan karir. Dengan adanya aspek perkembangan wawasan dan kesiapan karir setiap individu dituntut untuk dapat merencanakan dan menentukan karirnya sesuai dengan potensi, bakat/minat, kepribadian, gaya hidup, tanggung jawab sosial yang sesuai dengan dirinya dan diharapkan mencapai kemandirian dalam menentukan pilihan karir (Sari \& Nuryono, 2014).

Siswa SMA Bayt Al-Hikmah masih lemah dalam merumuskan alternatif pilihan, memprioritaskan alternatif di pilihan pertama, dan melaksanakan solusi dan mengevaluasi hasil yang masih perlu bimbingan intens dalam konseling karier berkaitan dengan masa depannya. Oleh karena itu, peneliti mencoba untuk mengembangkan panduan portofolio karier bagi siswa Bayt Al-Hikmah berharap, siswa secara kognitif aktif dalam merumuskan pilihan, lalu memprioritaskan pilihan karier hingga mampu melaksanakan solusi dari pilihan karier yang siswa mampu didalamnya. Trait and Factor bertujuan untuk mengajak klien berpikir mengenai dirinya dan menemukan masalah dirinya serta mengembangkan cara-cara untuk keluar dari masalah tersebut. Secara umum, konseling trait and factor (Susilowati, 2015) dimaksud untuk membantu klien dalam (1) klarifikasi diri (self clarification), (2) pemahaman diri (self understanding), (3) pengarahan diri (self acceptance), (4) pengarahan diri (self direction), dan (5) aktualisasi diri (self actualization). Pengembangan panduan portofolio karier tersebut mencoba mengaktifkan kembali klarifikasi diri siswa sehingga memberikan pemhaman serta pengarahan hingga siswa mampu mengaktualisasikan dirinya dalam bentuk persiapan perencanaan karier portofolio sebagai persiapan studi lanjutnya atau pilihan kerjanya. Adapun Rancangan Hipotetik dari pengembangan panduan portofolio karier bagi siswa SMA Bayt Al-Hikmah ditunjukkan pada gambar 1. 

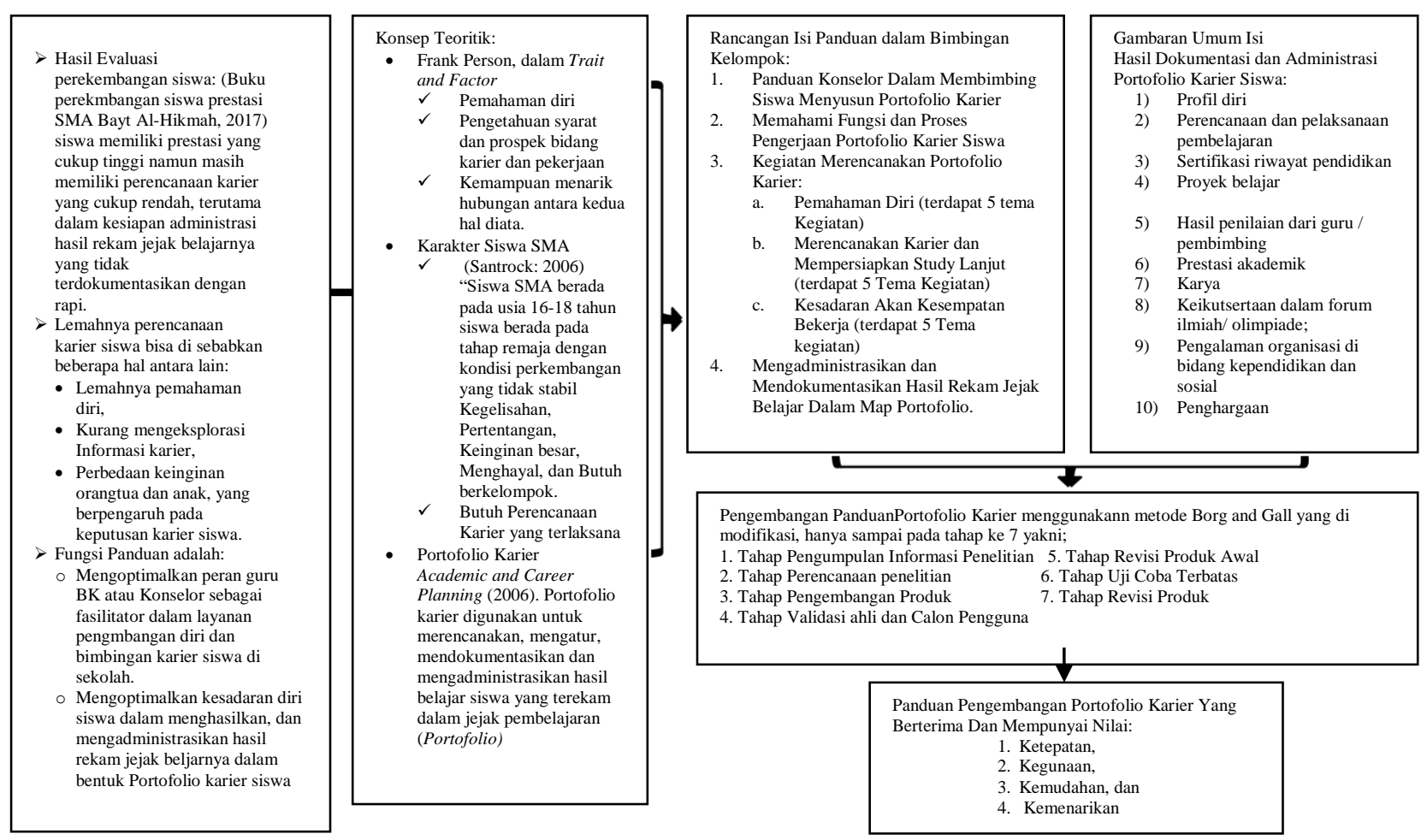

\section{Gambar 1. Rancangan Hipotetik Pengembangan Panduan Portofolio Karier Bagi Siswa SMA Bayt Al-Hikmah}

\section{METODE}

Jenis penelitiaan pengembangan panduan portofolio karier ini menggunakan pendekatan penelitian dan pengembangan (Research and Development, Borg dan Gall dalam (Albinus, 2018). Dalam pendidikan disebut Research Based Development dikembangkan sebagai strategi yang bertujuan untuk meningkatkan kualitas pendidikan. Lebih khusus dinyatakan bahwa, research and development adalah suatu proses yang digunakan untuk mengembangkan dan memvalidasi produk Pendidikan serta menemukan pengetahuan baru melalui "basic research", dan bertujuan untuk memberikan perubahan pendidikan guna meningkatkan dampak positif yang potensial dari temuan-temuan penelitian dalam memecahkan permasalahan pendidikan dan digunakan untuk meningkatkan kinerja praktik-praktik pendidikan. Rancangan penelitian pengembangan ini menggunakan model R\&D Borg and Gall (1983) yang dimodifikasi. Subjek dari penelitian pengembangan ini adalah siswa SMA Baytal-Hikmah dengan sample 20 orang yang diambil secara acak. Untuk mengetahui sejauh mana perbedaan.

Pengembangan panduan karier portofolio bagi siswa SMA Bayt Al-Hikmah ini dalam prosesnya dilakukan hanya sampai pada tahap ke tujuh saja, yakni tahap revisi produk setelah uji coba terbatas. Adapun tahapan pengembanganya adalah sebagai berikut. Pertama, tahap pengumplan informasi penelitian. Tahap mengkaji dan mengumpulkan informasi, mengkaji literasi, mengobservasi, interviuw dan menyiapkan laporan tentang kebutuhan Pengembangan. Kedua, tahap perencanaan penelitian merumuskan tujuan, merencanakan outline, menentukan kegiatan bimbingan, dan menyusun skala pengukuran dan uji terbatas. Ketiga, pengembangan produk, yakni menyusun/mengembangkan produk awal/ prototipe awal yakni pengembangan panduan karier portofolio. Keempat, validasi ahli dan calon pengguna. Tahap melakukan treatment/ujicoba terbatas terhadap produk awal (termasuk melakukan pengamatan, interview, dan angket). Kelima, Tahap revisi produk awal, yakni melakukan perbaikan terhadap produk awal yang dihasilkan berdasarkan hasil dari validasi ahli dan calon pengguna. Keenam, uji coba terbatas penerapan uji coba lapangan (observasi, interview, dan angket, pretes, dan postest). Ketujuh, revisi Produk yakni melakukan revisi produk berdasarkan hasil uji coba lapangan.

Data penelitian produk dilakukan dengan teknik kuesioner penilaian produk dan data kuesioner kebutuhan panduan pengembangan portofolio karier perenanaan karier siswa bagi calon pengguna. Analisa uji produk dalam penelitian ini menggunakan adalah tehnik inter-rater agreement oleh ahli BK dan ahli media (Komalasari, 2015), sedangkan untuk uji efektivitas calon pengguna menggunakan uji $t$-tes, yakni uji beda sebelum dan sesudah menggunakan panduan portofolio karier bagi perencanaan karier siswa. 


\section{HASIL}

Hasil penelitian pengembangan panduan portofolio karier bagi siswa SMA Bayt Al-Hikmah ini menunjukkan bahwa penilaian dari Ahli BK menunjukkan indeks sebesar 0,92 dan uji ahli media, menunjukkan Indeks sebesar 0.93, dan uji calon pengguna menunjukkan indeks 0.88. Dari perhitungan tersebut menunjukkan keberterimaan panduan portofolio karier siswa memiliki indeks tinggi dari segi ketepatan, kegunaan, kemudahan, dan kemenarikan yang tinggi seperti yang tertera pada tabel 2. Data disajikan dalam bentuk data kuantitatif yakni berupa hasil penilaian kuesioner dari ahli bimbingan dan konseling, ahli media dan calon pengguna dengan menggunakan teknik inter-rater agreement. Adapun tabel 2 menjelaskan hasil penilaian dari ahli BK, ahli media, dan calon pengguna.

Tabel 2. Hasil Uji Inter-Rater Agreement Pengembangan Panduan Portofolio Karier Bagi Siswa SMA Bayt Al-Hikmah

\begin{tabular}{|c|c|c|c|c|c|c|c|}
\hline \multirow[t]{2}{*}{ No } & \multirow[t]{2}{*}{ Validator } & \multicolumn{4}{|c|}{$\begin{array}{l}\text { Nilai Hasil Relevansi } \\
\text { Inter-Rater Kedua Ahli }\end{array}$} & \multirow{2}{*}{ Hasil Indeks $=\frac{D}{A+B+C+D}$} & \multirow[t]{2}{*}{ Keterangan } \\
\hline & & $\mathbf{A}$ & B & $\mathbf{C}$ & D & & \\
\hline 1. & Uji Ahli Bimbingan dan Konseling 1 dan 2 & 0 & 0 & 2 & 23 & 0,92 & Tinggi \\
\hline 2. & Uji Ahli Media 1 dan 2 & 0 & 1 & 0 & 59 & 0,96 & Tinggi \\
\hline 3. & Uji Calon Pengguna 1 dan 2 & 0 & 5 & 1 & 28 & 0,88 & Tinggi \\
\hline
\end{tabular}

Data deskriptif disajikan dari hasil pendapat ahli bimbingan dan konseling, ahli media dan calon pengguna yang dianalisis dari produk yang akan direvisi. Penyajian data deskriptif dari para ahli BK adalah sebagai berikut. Pertama, penulisan judul hendaknya mewakili isi. Kedua, isi kegiatan lebih disesuaikan dengan tujuan yang akan dicapai. Ketiga, dilengkapi dengan materi yang disajikan dan dinamika kelompok lebih bagus lagi. Keempat, sinopsis hendaknya menggunakan bahasa yang mudah dipahami dan menarik pembaca. Kelima, lebih bagus lagi dilengkapi dengan foto profil dan riwayat penulis dan prestasi penulis jika ada. Adapun hasil data deskriptif dari ahli media adalah sebagai berikut. Pertama, penulisan tata letak judul cover hendaknya lebih di sesuaikan dengan tema cover. Kedua, pemilihan warna cover sudah bagus, sesuai dengan tema karakteristik siswa. Ketiga, tata letak penulisan judul dan gambar harus dis esuaikan dengan fungsi dan tema panduan. Keempat, konsitensi penulisan judul dan headline. Kelima, cover belakang hendaknya diisi sinopsis dan riwayat penulis.

Untuk uji terbatas pada produk awal peneliti menggunakan instrument kebutuhan panduan portofolio karier dalam perencanaan karier siswa dengan validitas dan realibilitas tinggi yakni menunjukkan angka 0,9531. Untuk menguji efektifitas produk awal dianalisis dengan menggunakan uji beda atau t-test (Kunlasomboon, Wongwanich, and Suwanmonkha, 2015) yakni uji perbedaan dalam sebelum dan sesudah menggunakan panduan bagi perencanaan karier siswa, Dari hasil analisis uji beda dapat dilihat nilai beda rata-rata tingkat perencanaan karier sebelum dan sesudah menggunakan panduan sebesar 76.736 dan 81,263 signifikansi mean sebesar 0.00 dan itu $\leq 0.05$ artinya terjadi perbedaan yang signifikan terhadap perencanaan karier dari sebelum dan sesudah menggunakan panduan.

Tabel 3. Hasil Uji Perbedaan Sebelum dan Sesudah Penggunakan Panduan Pengembangan Portofolio karier bagi Siswa SMA Bayt Al-Hikmah

\begin{tabular}{|c|c|c|}
\hline \multicolumn{3}{|c|}{ t-test: Two-Sample Assuming Unequal Variances } \\
\hline & sebelum & sesudah \\
\hline Mean & 76,7368 & 81,2632 \\
\hline Variance & 29,9825 & 12,2047 \\
\hline Observations & 19 & 19 \\
\hline Hypothesized Mean Difference & 0 & \\
\hline df & 31 & \\
\hline t Stat & $-3,03761$ & \\
\hline $\mathrm{P}(\mathrm{T}<=\mathrm{t})$ one-tail & 0,0024 & \\
\hline t Critical one-tail & 1,69552 & \\
\hline $\mathrm{P}(\mathrm{T}<=\mathrm{t})$ two-tail & 0,00481 & \\
\hline t Critical two-tail & 2,03951 & \\
\hline
\end{tabular}

Adapun grafik perbedaan hasil uji sebelum dan sesudah menggunakan panduan portofolio karier sebagaimana ditunjukkan pada gambar 2 . 


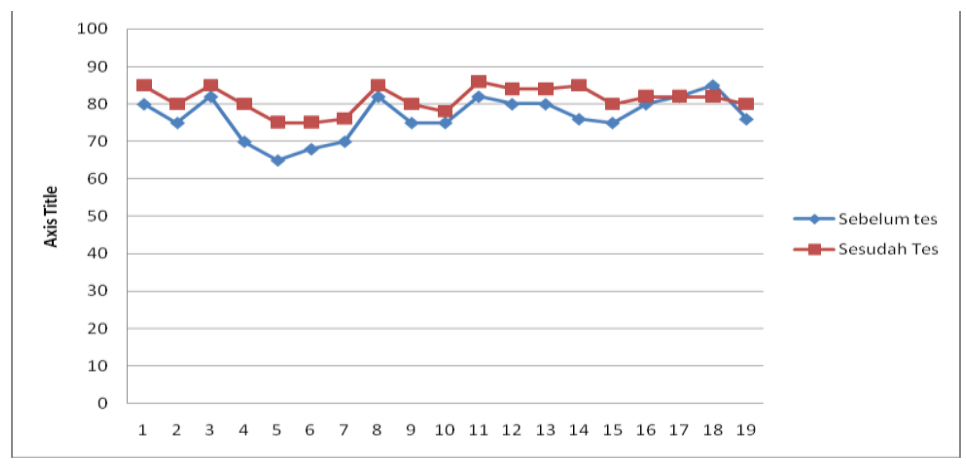

\section{Gambar 2. Grafik Skor Sebelum dan Sesudah Perencanaan Portofolio Karier}

Dari grafik di atas ada perbedaan perencanaan karier siswa yang cukup signifikan sebelum dan sesudah penggunaan panduan portofolio karier siswa.

\section{PEMBAHASAN}

Pengembangan Panduan Portofolio Karier Bagi Siswa SMA Bayt Al-Hikmah adalah panduan yang dikembangkan dengan tujuan menghasilkan panduan portofolio karier siswa yang berterima, dari segi ketepatan, kegunaan, kemudahan, dan kemenarikan sehingga dapat membantu siswa SMA Bayt Al-Hikmah dalam perencanaan karier yang lebih baik. Pelaksanaan bimbingan dan konseling karier menurut teori trait and factor (Susilowati, 2015) seorang guru BK atau konselor harus mampu memahami sifat diri/dimensi kepribadian dari konseli, sehingga mampu memahami konseli saat mengalami masalah karier dalam kehidupannya. Jika seorang konseli sudah mampu mengenali atau memahami dirinya sendiri, maka konseli tersebut tidak akan mengalami kesulitan dalam memilih karier yang sesuai dengan potensi atau kemampuan yang dimilikinya. Perkembangan karier siswa memang sering mengalami naik turun, terkait kondisi psikologis, lingkungan sosial pertemanan, dan dukungan keluarga, terutama keinginan orangtua yang mendominasi pilihan karier siswa, sehingga tidak jarang banyak siswa kurang stabil dalam mengkondisikan pilihan kariernya.

Pilihan karier tidak hanya ditentukan oleh sifat diri/dimensi kepribadian dari konseli, melainkan guru BK atau konselor juga harus mampu memberikan data mengenai pengalaman kerja dan latar belakang individu (konseli) pada umumnya (Meijers, Kuijpers, \& Gundy, 2013) sehingga guru BK atau konselor dapat mengenal kemampuan dan minat siswa sesuai harapan orang tuanya. Pengembangan panduan portofolio karier ini adalah sebagai salah satu bentuk optimalisasi kegiatan bimbingan dan konseling atau konselor di sekolah dalam membimbing dan mengarahkan siswa pada jejang karier yang tepat sesuai minat dan harapan siswa. Tujuan dalam Trait and Factor (Sari \& Nuryono, 2014) mengajak klien berpikir mengenai dirinya dan menemukan masalah dirinya serta mengembangkan cara-cara untuk keluar dari masalah tersebut. Secara umum, konseling trait and factor dimaksud untuk membantu klien dalam (1) klarifikasi diri (self clarification), (2) pemahaman diri (self understanding), (3) pengarahan diri (self acceptance), (4) pengarahan diri (self direction), dan (5) aktualisasi diri (self actualization).

Pengembangan panduan portofolio karier tersebut mencoba mengaktifkan kembali klarifikasi diri siswa, sehingga memberikan pemhaman serta pengarahan hingga siswa mampu mengaktualisasikan dirinya dalam bentuk persiapan perencanaan karier melalui kegiatan yang dapat menghasilkan portofolio. Dalam penelitian pengembangan panduan portofolio karier bagi siswa SMA, peneliti menggunakan metode bimbingan kelompok. Bimbingan kelompok cukup efektif dalam pengembangan kegiatan siswa dalam menghasilkan portofolio karier, selain dapat meningkatkan sosial emosional dalam membangun pemahaman diri, juga dapat meningatkan core work skill (Buchori, 2015). Pengembangan Portofolio karier siswa ini didalamnya siswa melakukan kegiatan sesuai tema, hasil dari kegiatan tersebut, baik berupa proposal kegiatan, karya, foto dokumentasi, sertifikat, dan penghargaan yang kemudian diadministrasikan hasil rekam jejak belajar tersebut, baik di bidang akademik maupun nonakademik dalam bentuk portofolio karier.

Menurut Maine Career Advantage (The Maine Tchnical College System, 2003) portofolio karier adalah representasi visual dari kemampuan, keterampilan, pengetahuan, kualitas, dan potensi. Secara fisik, portofolio karier adalah kumpulan hal nyata yang mewakili peristiwa yang berhubungan dengan pekerjaan dalam hidup. Dalam metode Portofolio Karier ini siswa mengumpulkan komponen-komponen portofolio yang diberikan oleh pembimbing yang dapat membantu siswa dalam pembangunan kariernya. menurut Nancy Perry dan Zark Van Zandt dalam (Prastiwi Rahmawati Ayu, 2015), Dalam kurikulum integratif pengembangan portofolio karier sangat berpengaruh seperti apa yang sudah dikembangkan di Kalifornia dalam kelas bimbingan kariernya (Career Resource Network, 2009). Portofolio dalam penelitian lain juga digunakan sebagai tolok ukur profesionalisme seorang guru dalam proses mengajarnya, seperti dalam penelitian yang dikembangkan oleh (Sri, 2008) dalam Profesional Development Trough Teaching Porfesionalisme. Pengembangan Portofolio Karier juga sangat dibutuhkan dalam pendidikan seni, seperti dalam pengembangan yang dilakukan oleh (Oscario \& Zahra, 2016) dalam strategi penyajian Portofolio Desain, ada banyak pengembangan lainnya yang sudah 
dilakukan oleh beberapa peneliti professional di bidangnya, mereka juga mengembangkan instrumen pengukur yang tepat dengan menggunakan e-Portofolio (Nurhayat Rosyida, Fetyi, \& Sumbawati, 2014). Bimbingan Karier merupakan metode yang membuat siswa akan menempatkan pekerjaan, dan rencana studi lanjutnya dalam portofolio mereka. Dalam dunia pendidikan, portofolio merupakan kumpulan hasil karya seorang siswa sebagai hasil dari rekam belajarnya atau hasil kinerja yang ditentukan guru (Zuclich, Yankowski, \& Prodans, 2016). Portofolio dalam pendidikan adalah bagian dari usaha dalam mencapai tujuan belajar atau mencapai kompetensi yang ditentukan dalam kurikulum (Utami, 2015).

Dalam penelitian pengembangan panduan karier portofolio bagi siswa SMA Bayt Al-Hikmah ini dalam prosesnya dilakukan hanya sampai pada tahap ke tujuh saja, yakni tahap revisi produk setelah uji coba terbatas. Data penelitian produk dilakukan dengan teknik kuesioner penilaian produk dan data kuesioner kebutuhan panduan pengembangan portofolio karier perenanaan karier siswa bagi calon pengguna. Analisa uji produk dalam penelitian ini menggunakan adalah teknik inter-rater agreement oleh ahli BK dan ahli media dalam (Wagner, 1998), sedangkan untuk uji efektivitas calon pengguna menggunakan uji $t$-tes, yakni uji beda sebelum dan sesudah menggunakan panduan portofolio karier bagi perencanaan karier siswa.

Hasil penelitian pengembangan panduan portofolio karier bagi siswa SMA Bayt Al-Hikmah ini menunjukkan bahwa penilaian dari Ahli BK menunjukkan keberterimaan panduan portofolio karier siswa memiliki indeks tinggi dari segi ketepatan, kegunaan, kemudahan, dan kemenarikan yang tinggi. Artinya, konselor membutuhkan panduan portofolio karier sebagai fasilitator dalam membantu bimbingan dan layanan karier pada siswa, sedangkan untuk menguji keefektifan panduan, peneliti melakukan uji coba produk awal dengan analisa menggunakan uji beda atau $t$-test (Buchori, 2015) yakni uji perbedaan dalam sebelum dan sesudah menggunakan panduan portofolio karier bagi perencanaan karier siswa. Dari hasil analisis uji beda dapat dilihat nilai beda rata-rata tingkat perencanaan karier sebelum dan sesudah menggunakan panduan sebesar 76.736 dan 81,263 signifikansi mean sebesar 0.00 dan itu $\leq 0.05$ artinya terjadi perbedaan yang signifikan terhadap perencanaan karier dari sebelum dan sesudah menggunakan panduan.

Penelitian pengembangan panduan portofolio karier ini juga mendukung penelitian sebelumnya yang juga berkaitan dengan penelitian sebelumnya antara lain Career Counseling Program to Improve Maturity Student of SMK, (Saifuddin, Ruhaena, \& Pratisti, 2017) dimana penelitian ini menunjukkan (1) kematangan karier siswa secara umum di SMK N 11 Bandung berkategori sedang, (2) indikator yang memiliki persentase terbesar adalah keterlibatan, independensi, dan pemilihan pekerjaan, sementara indikator terendah adalah kompromi, pemahaman diri, dan pengetahuan pekerjaan, (3) program bimbingan karier efektif untuk meningkatkan kematangan karier siswa. Dalam sebuah artikel penelitian yang berjudul Profesional Development Through Teaching Portofolio dalam (Wijayanti, 2008) juga menjabarkan tentang efektifvas mengajar melalui portofolio yakni bahwa guru sebagai profesional harus menyadari pentingnya profesi. Portofolio adalah salah satu media pengembangan professional yang membuat para guru dapat mengikuti perkembangan terkini dalam pendidikan, membantu guru dalam membuat inovasi, dan memperbaiki praktik guru dalam mendidik. Latihan reflektif, salah satunya adalah menyusun portofolio pengajaran, dapat menjadi dasar pengembangan profesional (Nurhayat Rosyida, Fetyi, \& Sumbawati, 2014).

Dalam penelitian pengembangan ini, peneliti mencoba merancang sebuah media yang mampu membuat antara murid dan guru berkolaborasi dengan baik agar rekam jejak pembelajaran mampu didministrasikan dengan baik, dan berbukti otentik, agar jejak rekam hasil belajarnya sama sama dapat digunakan sebagai persiapan perencanaan karier studi lanjutnya yang berdampak pada kematangan kariernya. Dari penelitian tentang portofolio karier diatas dapat mendukung pengembangan panduan portofolio karier bagi siswa SMA Bayt Al-Hikmah yang memang dapat membantu memfasilitasi guru BK/ konselor dalam layanan bimbingan karier siswa di sekolah karena dapat membantu pemahaman diri siswa dalam persiapan perencanaan karier kedepannya.

\section{SIMPULAN}

Penelitian pengembangan ini menghasilkan produk berupa buku panduan portofolio karier yang didalamnya dilengkapi map portofolio bagi siswa dalam mengadministrasikanhasil rekam belajar siswa. Pengembangan panduan portofolio karier ini dikembangkan dengan model Borg \& Gall (1985) yang dimodifikasi. Materi yang dibahas pada produk pengembangan panduan portofolio karier bagi siswa SMA ini adalah panduan singkat konselor dalam membimbing siswa untuk mengadministrasikan portofolio (ABKIN 2018). Kegiatan layanan bimbingan karier untuk siswa SMA terdiri atas (1) pemahaman diri remaja yang didalamya ada lima kegiatan yang mendorong siswa untuk menghasilkan profil diri atau Curriculum Vitae, (2) perencanaan Karier Siswa, yang terdiri atas lima kegiatan yang memotivasi untuk bisa menghasilkan portofolio karier dalam, (3) peluang kerja yang didalamnya berisi lima kegiatan yang dapat membimbing siswa memanfaatkan informasi dan peluang kerja, dan (4) menyusun dan mengadministrasikan portofolio dari kegiatan yang sudah dilaksanakan dalam map portofolio yang sudah tersedia.

Produk pengembangan panduan ini divalidasi oleh ahli media, ahli bimbingan dan konseling. Hasil analisis data dari ahli bimbingan dan konseling sebesar 0.92 yang menunjukkan validitas cukup tinggi, dan Indeks uji ahli media menunjukkan 0.93 yang berarti memiliki validitas yang tinggi juga. Jadi, dapat disimpulkan bahwa panduan portofolio karier ini secara umum layak dipakai dengan perbaikan yang disarankan. Adapun hasil analisis data dari postest dengan menggunakan analisis $t$-test by excel menunjukkan taraf signifikansi $0,00<0,05$, yang artinya terdapat perbedaan perencanaan karier sebelum dan sesudah 
penggunaan panduan portofolio. Adapun relevansi dari perhitungan calon pengguna dengan indeks uji ahli pengguna menunjukkan 0.96 yang berarti memiliki validitas yang Tinggi. Dengan demikian, dapat disimpulkan bahwa panduan portofolio karier ini secara umum layak dipakai dengan perbaikan yang disarankan. Nilai rata-rata kelas tindakan yang menggunakan produk pengembangan adalah 81,51, sedangkan kelas kontrol yang tidak menggunakan produk pengembangan adalah 74,67. Dari penjelasan di atas, dapat dikatakan bahwa produk pengembangan media portofolio karier bagi siswa SMA Bayt AlHikmah memang valid dan efektif serta layak untuk digunakan dengan sedikit revisi dan pengembangan sesuai kebutuhan selanjutnya.

Saran dari ahli Bimbingan dan Konseling dalam proses validasi produk pengembangan panduan portofolio karier bagi siswa SMA Bayt Al-Hikmah adalah sebagai berikut. Pertama, diharapkan guru BK atau Konselor di SMA Bayt Al-Hikmah menggunakan panduan pengembangan portofolio karier dalam melaksanakan layanan dan bimbingan karier di sekolah. Kedua, diharapkan Guru BK atau Konselor SMA Bayt Al-Hikmah mampu menggunakan dan mengevaluasi hasil panduan pengembangan portofolio karier ini selama proses layanan dan bimbingan karier siswa. Ketiga, diharapkan mampu mengembangkan penelitian dengan uji sampel yang lebih banyak sehingga dapat igunakan pada sekolah yang lebih luas juga. Saran yang diberikan oleh ahli media pengembangan panduan portofolio karier bagi siswa SMA Bayt Al-Hikmah adalah sebagai berikut. Pertama, diharapkan guru BK atau Konselor dengan produk yang dikembangkan dapat lebih kreatif dan optimal dalam memfasilitasi kebutuhan siswa dalam layanan dan bimbingan karier. Kedua, diharapkan guru BK atau Konselor dapat melakukan evaluasi dari produk yang dikembangkan sehingga panduan dapat dikembangkan sesuai kebutuhan terkini. Saran dari calon pengguna, bagi siswa diharapkan dengan menggunakan portofolio karier, siswa mampu mendokumentasikan dan mengadministrasikan hasil rekam jejak belajarnya menjadi lebih baik dalam map portofolio yang sudah tersedia sehingga lebih siap administratif dengan segala persyaratan yang dibutuhkan kelak sesuai dengan pilihan karier siswa.

\section{DAFTAR RUJUKAN}

Albinus, S. (2018) Development Research \& Research and Development ResearchGate. doi: 10.13140/RG.2.2.13429.88803/1.

Atmaja, T. T. (2014) Upaya Meningkatkan Perencanaan Karir Siswa Melalui Bimbingan Karir dengan Penggunaan Media Modul. PSIKOPEDAGOGIA: Jurnal Bimbingan dan Konseling, 3(2), 58-68. http://dx.doi.org/10.12928/psikopedagogia.v3i2.4466

Buchori, S. (2015). Efektivitas Bimbingan Karier untuk Peningkatan Core Work Skills Mahasiswa. Jurnal Psikologi Pendidikan \& Konseling, 1(1), 58-65. https://doi.org/10.26858/jpkk.v1i1.1289

Hanani, Z. (2016) Pengembangan Kartu Karir sebagai Media Bimbingan Karir Siswa SD. Yogyakarta.

Juwitaningrum, I. (2013). Program Bimbingan Karir untuk Meningkatkan Kematangan Karir Siswa SMK. PSIKOPEDAGOGIA: Jurnal Bimbingan dan Konseling, 2(2), 132-147. doi: 10.12928/psikopedagogia.v2i2.2580.

Komalasari, G., \& Herdi. (2015). The Development of Career Competence Instrument Based on Computer Assisted Testing for Students of Junior High Schools in Jakarta, Indonesia. American Journal of Engineering Research, 4(12), 28-35.

Meijers, F., Kuijpers, M., \& Gundy, C. (2013). The Relationship Between Career Competencies, Career Identity, Motivation and Quality of Choice. International Journal for Educational and Vocational Guidance, 13(1), 47-66. doi: 10.1007/s10775-012-9237-4.

Muslihati. (2019). Peran Bimbingan dan Konseling dalam Penguatan Pendidikan Karakter di Sekolah Menengah Kejuruan. Jurnal Kajian Bimbingan dan Konseling, 4(3), 101-108. doi: 10.17977/um001v4i32019p101.

Nurhayati, F. R., \& Sumbawati, M. S. (2014). Pengembangan e-Portfolio sebagai Instrumen Penelitian Siswa di SMK Negeri 2 Lamongan. Jurnal Pendidikan Teknik Elektro, 3(1), 253-259.

Prastiwi, A. R. (2015). Upaya Peningkatan Kematangan Karir melalui Metode Career Portofolio pada Siswa Kelas X- MIA di SMA N 1 Boyolali. Jurnal Riset Mahasiswa Bimbingan dan Konseling, 4(9), 1-13.

Saifuddin, A., Ruhaena, L., \& Pratisti, W. D. (2017). Meningkatkan Kematangan Karier Peserta Didik SMA dengan Pelatihan Reach Your Dreams dan Konseling Karier. Jurnal Psikologi, 44(1), 39. doi:10.22146/jpsi.17378.

Sari, N. Y., \& Nuryono, W. (2014). Pengembangan Buku Panduan Orangtua untuk Mendukung Perencanaan Karir Siswa di Madrasah Aliyah Negeri Sidoarjo. Jurnal BK UNESA, 8(1), 1-7.

Susilowati, D. (2015). Efektivitas Strategi Holland Types For Career Counseling dan Strategi Solution-Focused Career Counseling untuk Peningkatan Kematangan Karir (Studi terhadap Peserta Didik Kelas X SMA Negeri 1 Kota Cimahi). Tesis tidak diterbitkan. Universitas Pendidikan Indonesia, Bandung.

Utami, N. R. (2015). Efektivitas E-Portofolio Menggunakan Edmodo terhadap Keaktifan dan Hasil Belajar Siswa pada Mata Pelajaran Fotografi Kelas X Jurusan Multimedia di SMK Negeri 2 Sewon. Tesis tidak diterbitkan. Universitas Negeri Yogyakarta.

Zuclich, I., Yankowski, A., \& Prodans, R. (2016) Developing a Career Portfolio Career and Employment Service (CES) Committee AIHce CareerAdvantage Development Fair 2016 Presenters. 